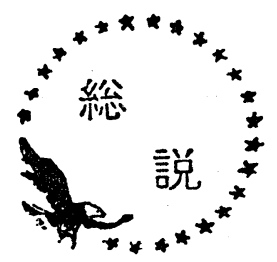

\title{
モレタナ式吸収装置による $\mathrm{NO}_{\bar{x}}^{-}, \mathrm{SO}_{x}$ 同時除去法
}

1975年12月 16 日受理

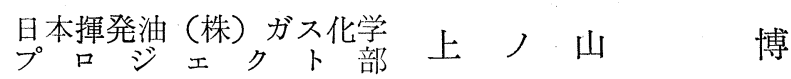
早川健一

\section{1. はじめに}

光化学スモッグの原因の一つといわれる窒素酸化物 が, 数年来大さな環境問題としてクローズアップし, その対応策として排煙脱硝技術の開発に今日最大限の 努力が傾注されている。

窒素酸化物は, 硫黄酸化物と比べて, きわめて反応 性にとぼしく, 特に排煙中の $\mathrm{NO}_{x}$ のような低濃度の 場合には除去方法が技術的に不可能ではないにしろ, その処理を単独で行なら場合には多大の費用を必要と する。すなわち脱硫費としてかなりの支出を行なった 上, さらに脱硝のために同等あるいは, それ以上の経 済的支出を余儀なくされることは, 非常に大きな困難 を生み, あくまでも経済性を最重視した技術の開発が 渴望されている。従って脱硫設備になんらかの脱硝機 能を付加することにより同一設備で $\mathrm{SO}_{x}, \mathrm{NO}_{x}$ を同 時に除去することができれば，非常に理想的といえ る。

このよらな観点から開発されたモレタナ吸収装置に よる $\mathrm{SO}_{x}, \mathrm{NO}_{x}$ 同時除去法について以下に報告す る。

\section{2. 窒素酸化物の発生とその規制の現状}

2.1 窒素酸化物の環境基準

公害対策基本法第 9 条に定められている環境基準は 「人の健康の保護および生活環境の保全のために維持 することが望ましい基準」であり，公害防止対策を進 める行政上の目標でもめる。このような思想の基に昭 和48年 5 月に定められた環境基準には

1） 1 時間值の 1 日平均值が $0.02 \mathrm{ppm}$ 以下である こと

2. 測定法はザルツマン試薬を用いる吸光光度法に よること

と定められている。

また環境基準を達成すべき期間としては 5 年以内， すなわち昭和 52 年度内に達成することとなっている。
ただし人工集中地域や大規模工業地帯では污染が著し く進んで括り,これらの地域は例外的に 8 年以内に達 成することとなっている。しかし8年地域に和いても 昭和52年度中に中間目標として「環境基準を達成して いる日数が総日数の $60 \%$ 以上であること」を達成する こととなって和り, 東京, 大阪, 名古屋など 12 地域が この 8 年地域に定められている。これら環境基準達成 のため, 固定発生源に対する窒素酸化物排出基準が定 められ，現状では個々の施設に関しては，2段然焼， 排ガス再循環などの燃焼法の改善, あるいは低 $\mathrm{NO}_{x}$ バーナーの使用による燃焼機構の改善などにより基準 值の達成が可能といわれ, $\mathrm{NO}_{x}$ の低減化はすでに数 多く実現されている。

しかし我国の平地, 特に工場地帯, 人口密集地に拉 けるエネルギー消費量はきわめて多く, 全国 228 個所 で測定した $\mathrm{NO}_{x}$ の污染は予想外に大きく, 環境基準 を達成しているのはわずか 4 力所であり, 全国的に污 染の広がりのあることが分かっている。従って今後の 排出規制の強化に対応すべく, 脱硝技術の開発に, よ り一層の努力が必要とされている。

\section{2 窒素酸化物の発生源}

窒素酸化物は硫黄酸化物のように, 発生源が限定さ れておらず, 自然現象により発生する他, ボイラー, キルン, 焼結炉, 加熱炉などの固定発生源ばかりでな く, 自動車, ジェット機, 船舶などの移動発生源から も発生し，また硝酸プラントや銅，アルミ，ニッケル などのメッキ工程からも発生する。

主な固定発生源からの窒素酸化物排出状況は, 昭和 47年に抮いては表 1 のよらである。主要発生源はボイ ラー, セメントキルン, 鉄鋼焼結炉, コークス炉, 金 属加熱炉, 石油加熱炉であり, ボイラーが全体の60〜 70\%を占めている。

2.3 固定発生源からの窒素酸化物の排出規制 昭和48年に制定された固定発生源からの窒素酸化物 
表 1 主な施設の $\mathbf{N o}_{x}$ 排出濃度

$$
\begin{array}{cc}
\text { 施 } & \text { 設 } \\
\text { ボイラー } & \text { (液体燃料) } \\
\text { " } & \text { (気体燃料) } \\
\text { " } & \text { (固体燃料) }
\end{array}
$$$$
\text { 女メント焼成炉 }
$$$$
\text { 焼結炉 }
$$$$
\text { コ一ク ス 炉 }
$$$$
\text { ガラス溶融炉 }
$$$$
\text { 金属 加 熱 炉 }
$$$$
\text { 石 油加熱 炉 }
$$

硝 酸 製造 施 設

\begin{tabular}{rcr}
\multicolumn{3}{c}{$\mathrm{NO}_{x}$ 濃度 ppm } \\
最小 & 最 大 & 平 均 \\
92 & 600 & 280 \\
28 & 230 & 190 \\
270 & 1080 & 670 \\
140 & 1605 & 380 \\
71 & 350 & 210 \\
68 & 816 & 315 \\
310 & 1400 & 1030 \\
20 & 427 & 150 \\
85 & 350 & 150 \\
170 & 2000 & 800
\end{tabular}

施設数（概数）

$$
\begin{array}{r}
77,440 \\
100 \\
1,650 \\
230 \\
60 \\
230 \\
1,400 \\
5,900 \\
1,350 \\
45
\end{array}
$$

\section{表 2 窒素酸化物の排出基準}

施設の種類 建 設 時 期 $\overbrace{\text { (旧基準) (新基準) }}^{10 \text { 万 } \mathrm{Nm}^{3} / \mathrm{hr} \text { 以上 }}$

固体然焼ボイラー $\left\{\begin{array}{l}\mathrm{a} . \\ \mathrm{b} . \\ \mathrm{c} .\end{array}\right.$

原油・タール然焼 $\left\{\begin{array}{l}\mathrm{a} . \\ \mathrm{b} . \\ \mathrm{c} .\end{array}\right.$

その他ボイラー $\left\{\begin{array}{l}a . \\ b . \\ c .\end{array}\right.$

金属加熱炉 $\left\{\begin{array}{l}\mathrm{a} . \\ \mathrm{b} . \\ \mathrm{c} .\end{array}\right.$

石 油加熱炉 $\left\{\begin{array}{l}a . \\ b . \\ c .\end{array}\right.$

セメント焼成炉 $\left\{\begin{array}{l}a . \\ b . c\end{array}\right.$

コ一クス炉 $\begin{cases}a . \\ b .\end{cases}$

硝酸製造施設 $\left\{\begin{array}{l}a . \\ b .\end{array}\right.$

\section{旧}

100

130

130

480

480

480

750
旧基準 : 昭和 48 年制定

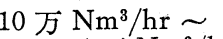

新基準 : 昭和50年制定 10 万 $\mathrm{Nm}^{3} / \mathrm{hr} \sim$ 1 万 $\mathrm{Nm}^{3} / \mathrm{hr}$ (旧基準) (新基準) $\overbrace{\text { (旧基準) (新基準) }}$ 130 130 150 150 480 750 750 480 600 600 150 280 280 150

180

180

$180 \quad 180$

$230 \quad 230$

100

$200^{\text {b) }} \quad 200^{\text {b) }}$

$220^{\mathrm{b}}$ ) $220^{\mathrm{b}}$

100

170c) $170^{\mathrm{c})}$

$210^{\mathrm{c})}$

250

200

200

200

200 $200 \quad 200$

200

a) 排煙脱硫装置を設置しているものを除く

b) 鍛接鋼管加熱炉を除く

c) エチンン分解炉とその独立加熱炉，メタノール改質炉，アンモニア改質炉を除く 
排出の旧基準は表 2 亿示す通りである。

旧基準ではボイラー，金属加熱炉，石油加熱炉扣よ び硝酸製造施設のみが規制の対象となって扔り, 窒素 酸化物は「有害物質」として扱われ，規制の方式は $\mathrm{NO}+\mathrm{NO}_{2}$ の濃度規制方式がとられている。

この排出規制は 2 段燃焼, 排ガス再循環などの燃焼 改善による方式を採用することにより，対策前の20〜 30\%を削減することを期待して出された数值である が，環境基準值への早期達成のためには，現排出量の $50 \%$ 程度の削減が必要ともいわれている。

最近発表された第 2 次規制は, 新基準として第 2 表 に示すように，従来対象となっていなかったコークス 炉，セメント暁成炉，並びに 1 万 $\mathrm{Nm}^{3} / \mathrm{hr}$ 以上の中 小ボイラーも対象に加光られている。特に新設の設備 に対する基準值は大幅な強化がなされ，一部の施設は 排煙脱硝や燃料の転換を必要とするまでに至ってい る。また $\mathrm{SO}_{2}$ とついては認められていない地方自治
体の上乗せ基準が, 窒素酸化物については認められて 扣り,川崎, 千葉地区などではすでに実施されている。

\section{3. 脱硝プロセスの分類}

燃焼に上り発生する窒素酸化物は, 大部分が NOで あり， $\mathrm{NO}_{2}$ は数\%にすぎない。 $\mathrm{NO}$ は応性にとぼし く触媒を使用して $\mathrm{Na}$ 飞還元するか, 酸化して $\mathrm{NO}_{2}$ にした後, 水溶液に吸収させるかまたは吸着剤による 吸着法などにより処理するプロセスが種々開発されつ つあるが，いゔれの場合にも工業的大規模装置に和い ては克服すべき問題が残されている。

以下に各種脱硝プロセスの簡単な分類をかかげる。 本稿に和いて紹介寸るモレタナ吸収装置による $\mathrm{SO}_{x}, \mathrm{NO}_{x}$ 同時除去法は, 気相で $\mathrm{NO}$ を酸化し, 液 相で亚硫酸塩による還元を行なわせる湿式プロセスで あり, 現在 4 基の工業プラントがすでに稼動し， 2 基 が目下建設中である。

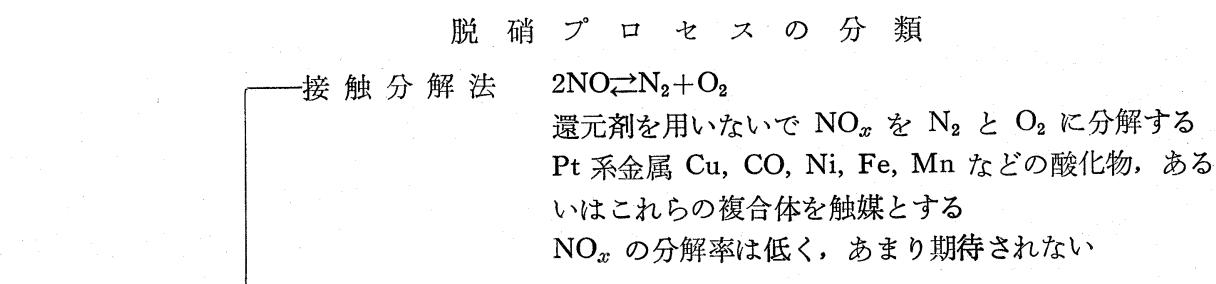

乾式プロセス一接触還元法

$\mathrm{CH}_{4}, \mathrm{H}_{2}, \mathrm{CO}$ などによる還元

$\mathrm{CH}_{4}+4 \mathrm{NO}_{2} \rightarrow 4 \mathrm{NO}+\mathrm{CO}_{2}+2 \mathrm{H}_{2} \mathrm{O}$

$\mathrm{CH}_{4}+2 \mathrm{O}_{2} \rightarrow \mathrm{CO}_{2}+2 \mathrm{H}_{2} \mathrm{O}$

$\mathrm{CH}_{4}+4 \mathrm{NO} \rightarrow 2 \mathrm{~N}_{2}+\mathrm{CO}_{2}+2 \mathrm{H}_{2} \mathrm{O}$

反応速度 $(1)>(2)>(3)$

反応温度 $400 \sim 500^{\circ} \mathrm{C}$

選 択 還 元 法

$\mathrm{NH}_{3}, \mathrm{H}_{2} \mathrm{~S}$ による還元

$4 \mathrm{NO}+4 \mathrm{NH}_{3}+\mathrm{O}_{2} \rightarrow 4 \mathrm{~N}_{2}+6 \mathrm{H}_{2} \mathrm{O}$

$2 \mathrm{NO}_{2}+4 \mathrm{NH}_{3}+\mathrm{O}_{2} \rightarrow 3 \mathrm{~N}_{2}+6 \mathrm{H}_{2} \mathrm{O}$

反応温度 $300 \sim 450^{\circ} \mathrm{C}$

一吸 着 法 活性炭, シリカゲル, モレキュラーシーブなどによる吸着

一アンモニア還元法 無触媒 $800 \sim 1000^{\circ} \mathrm{C}$

法

法

$\cdot \mathrm{NaOH}$ ，アンモニア，水なぞによる吸収

$\mathrm{NaOH}+\mathrm{NO} \rightarrow$ 反応せず

$2 \mathrm{NaOH}+\mathrm{N}_{2} \mathrm{O}_{3}\left(\mathrm{NO}+\mathrm{NO}_{2}\right) \rightarrow 2 \mathrm{NaNO}_{2}+\mathrm{H}_{2} \mathrm{O}$

$2 \mathrm{NaOH}+2 \mathrm{NO}_{2} \rightarrow \mathrm{NaNO}_{2}+\mathrm{NaNO}_{3}+\mathrm{H}_{2} \mathrm{O}$

酸飞よる吸収…… $\mathrm{H}_{2} \mathrm{SO}_{4}$ に上る吸収

$\mathrm{H}_{2} \mathrm{SO}_{4}+\mathrm{NO} \rightarrow \mathrm{H}_{2} \mathrm{SO}_{4} \cdot \mathrm{NO}$

$\mathrm{H}_{2} \mathrm{SO}_{4}+\mathrm{N}_{2} \mathrm{O}_{3}\left(\mathrm{NO}+\mathrm{NO}_{2}\right) \rightarrow 2 \mathrm{NOHSO}_{4}+\mathrm{H}_{2} \mathrm{O}$ 


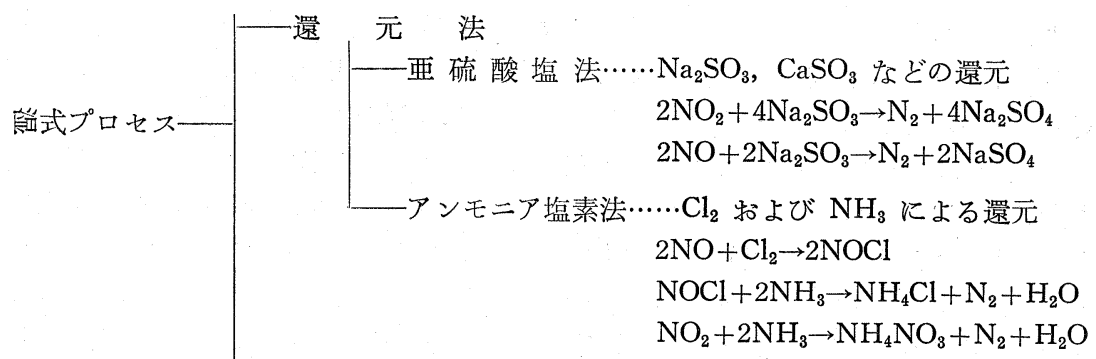

酸化吸収法

気相 酸 化法……オン゙ン, $\mathrm{ClO}_{2}$ で $\mathrm{NO}_{x}$ を酸化し水に吸収

$$
\begin{aligned}
& 3 \mathrm{NO}_{2}+\mathrm{H}_{2} \mathrm{O} \rightarrow 2 \mathrm{HNO}_{3}+\mathrm{NO} \\
& \mathrm{N}_{2} \mathrm{O}_{5}+\mathrm{H}_{2} \mathrm{O} \rightarrow 2 \mathrm{HNO}_{3}
\end{aligned}
$$

液相酸化法…… $\mathrm{NaClO}_{2}, \mathrm{KMnO}_{4}$ なぞによる酸化

$$
\begin{aligned}
& 2 \mathrm{NO}+\mathrm{NaClO}_{2} \rightarrow 2 \mathrm{NO}_{2}+\mathrm{NaCl} \\
& 4 \mathrm{NO}_{2}+\mathrm{NaClO}_{2}+4 \mathrm{NaOH} \rightarrow 4 \mathrm{NaNO}_{3}+\mathrm{NaCl}+\mathrm{H}_{2} \mathrm{O}
\end{aligned}
$$

錯塩生成吸收法….... $\mathrm{FeSO}_{4}, \mathrm{FeCl}_{2}, \mathrm{NiSO}_{4}$ などとよる錯塩の生成吸収

$$
\mathrm{FeSO}_{4}+\mathrm{NO} \rightleftarrows \mathrm{Fe}(\mathrm{NO}) \mathrm{SO}_{4}
$$

\section{4. モレタナ吸収装置}

モレタナ塔とは図1のように，断面が円形または角 形の塔内に多孔板棚を数段とりつけた空塔装置で，せ きや溢流部や充填物がなく，構造が極めて簡単である ことが特徴である。塔の上部には液滴分離器と液分配 器が, 塔の下部にはガス流が塔の断面にわたって均一 な速度分布を保つように合理的に設計されたガス整流 器がついている。

吸収液は液分配器から最上級の棚上飞供給され，塔 の下方から入ってきたガスと棚上で向流接触し, 激し く混合する気液混合層を形成し，物質移動，熱移動が 極めて迅速に行なわれる。液は棚の一部の孔から流下 し，残りの孔をガスが通って上昇する。棚の開孔部を ガスが上昇している場所では, 気液層の高さが次第に 高くなり，ある一定の高さに達すると，液の静水圧が 下段のガス压に打ち勝って液が流下するようになる。 一方液が流下している場所では気液層の高さが次第に 減少しある高さにまで下ると，下段のガス压が気液層 の液静水圧よりも大きくなるためガスが気液層を通過 し始める。このように棚上で液の流下する場所とガス の上昇する場所が順次交代して, 気液両相の接触が自 動的に行なわれるのが特徵である。

従来の多孔板棚は，液漏孔を無くすため，直径 1 $6 \mathrm{~m} / \mathrm{m}$ の小さい穴が用いられ, 棚の開孔比（塔断面 積に対する全孔面積の比）も20\%以下であり，ガスの 空塔速度は $1 \sim 2 \mathrm{~m} / \mathrm{sec}$ が最も多く用いられている。 また, 棚段からのウィーピングやエントレインメント
は段効率に対し最も大きく影響を与えるものとされ， これらをでき得る限り無くするよらに設計されて拉 り，また気液の接触時間を保持するため棚に，せきと 溢流部を設け液が棚を水平方向に流れ，ガスが棚に亦 けられた穴を通過することによる十字流の気液混合層 を形成するものが大多数をしめている。このような従 来の多孔板の常識を打ちやぶり，穴径の桩大あるいは 開孔比の大幅な拡大を行なった結果，従来注見られ なかった気液の流動特性や物質移動特性が見い出され た。

この種の研究は戦後のソ連の報告に多数見られるが 元静岡大学内山教授により, 開孔比 $30 \sim 60 \%$, ガス空 塔速度 $3 \mathrm{~m} / \mathrm{sec}$ 以上の条件の研究により, 今日の排脱 用モレタナ吸收装置の基本が固められた。モレタナと 従来の棚段との比較は通過ガス量と先の圧損の関係に 打いてまず明らかにされる。これを図 2 に示す。

図2 亿扔いて, 曲線（イ）は従来の多孔板または格 子状板塔を示し, 曲線（口）はモレ夕ナ塔を示す。モ レタナ塔，すなわち曲線（ロ）に拈いては，ガス空塔 速度 $\mathrm{U}_{g}$ の点 $\mathrm{A}$ から棚上飞液層が保持され, 空塔速 度 $\mathrm{U}_{g}$ の増大と共に, 緩やかに圧力損失 $\triangle \mathrm{P}$ が增加 して B 点洼する。従来の多孔板はこれ以上 $\mathrm{U}_{g}$ を 增すと溢汪現象を起こすが，モレタナ塔では $\mathrm{AB}$ 間 に比べやや高い圧力損失の増加率を示しながら，C 点 飞達し以後急速に圧力損失が増大し溢汪する。

実際の設計に䞌いては，開孔率，液ガス比招よび流 動特性を考慮し，物質移動効率を満足する範囲に特い 


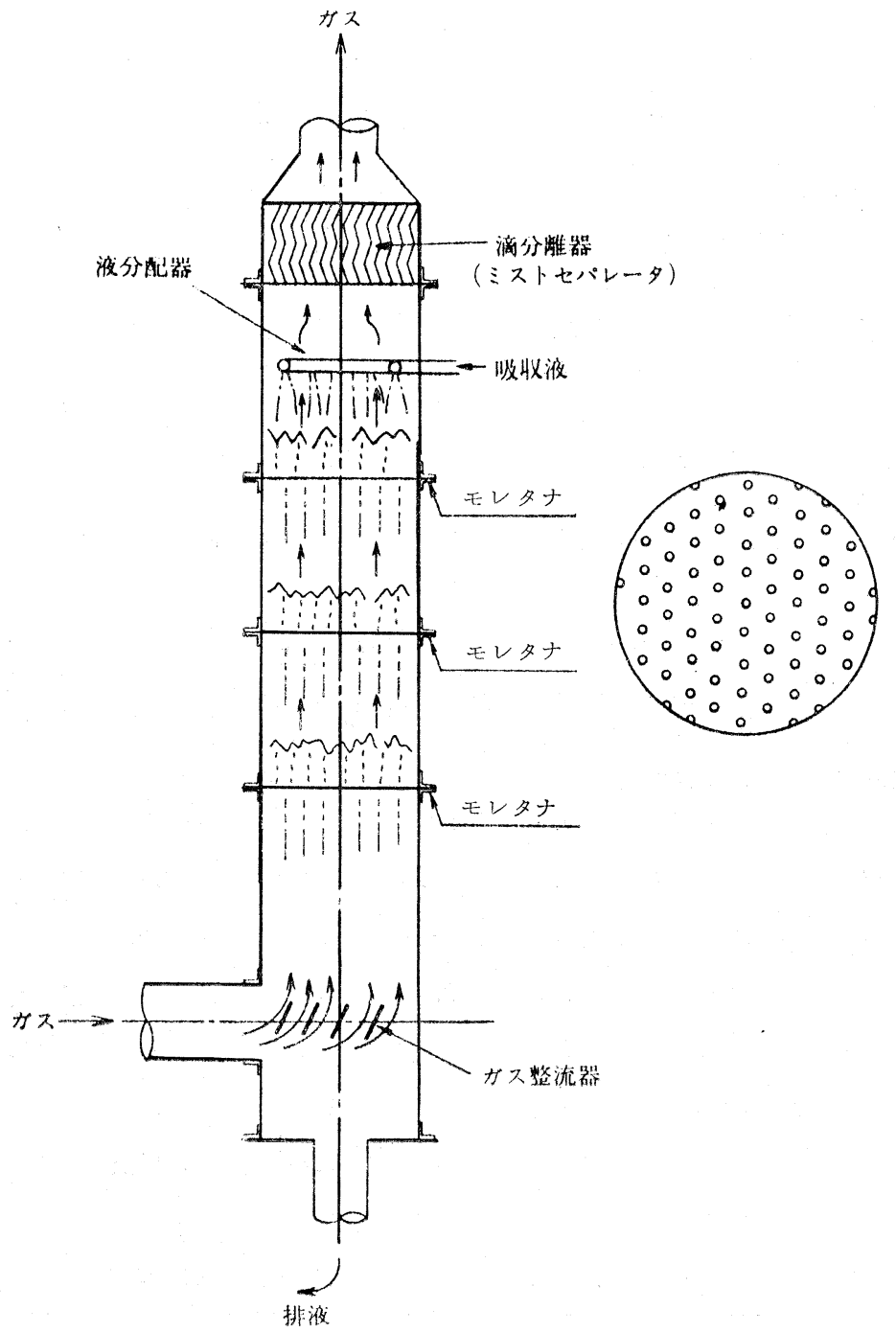

図1モレタナ塔の構造

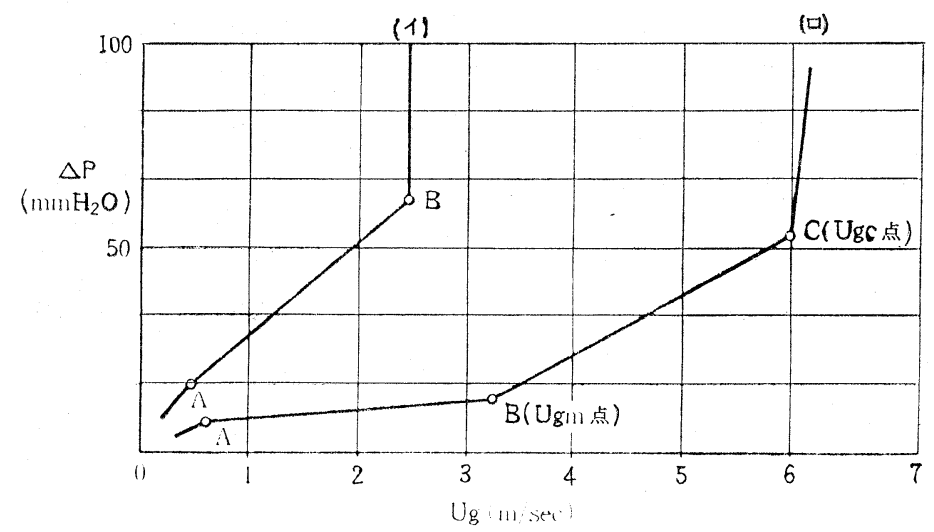

図暳2モレタナ圧損とガス空塔速度 
て，圧力損失を押さ光かつ $\mathrm{U}_{g}$ をできるだけ高くとれ るようにモレタナの形状を決定している。この結果排 煙脱硫装置の場合には開孔率30 40\%, 塔内空塔速度 $4.5 \sim 5 \mathrm{~m} / \mathrm{sec}$ が可能となり, 吸収装置は非常にコン パクトとなり同じ空塔容積で他の装置の $2 \sim 7$ 倍のガ ス量を処理することができる点で画期的である。

モレタナ吸収装置はこのような流動特性を持つばか りでなく, 気液混合特性に拉いても著しい特徵を有 し, 排煙脱硫装置の場合 $\mathrm{Na}$ 系あるいは $\mathrm{Ca}$ 系の吸収 液を使用し，99\%以上の脱硫率が確実であり，ほとん ぞ100\% 近く吸収することが実際の装置でしばしば見 られている。特に大型気液接触装置の場合には, 気液 の均一分散が設計上の最大のポイントとなるが，モレ
タナ自体が通過流体に対し整流機能を持っているた め, 複雑な構造の分配器などは一切不要である。

脱硫吸收剈に $\mathrm{Ca}$ 系スラリーを使用した場合，塔 内での $\mathrm{Ca}$ 塩の付着, 堆積, あるいは閉塞などの現象 が起こり，安定運転を阻害することがしばしばあると いわれているが，モレタナ吸収装置を使用した場合に は, 前述のごとく塔内での激しい混合作用により自か ら「自洗効果」を生ずるためスラリーによるトラブル は全く見られない。

表 3 亿モレタナ吸収装置を使用した排煙脱硫装置と 他の方法との比較を示す。

\section{5. $\mathrm{SO}_{x}, \mathrm{NO}_{x}$ 同時除去}

モレタナ吸収装置を用いた $\mathrm{SO}_{x}, \mathrm{NO}_{x}$ の同時除去

表 3 モレタノ塔と他の排煙脱硫装置との比較

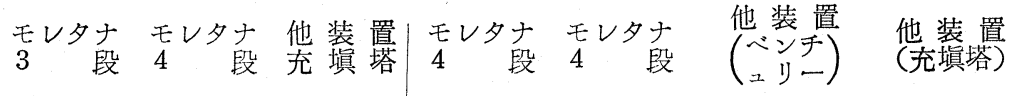

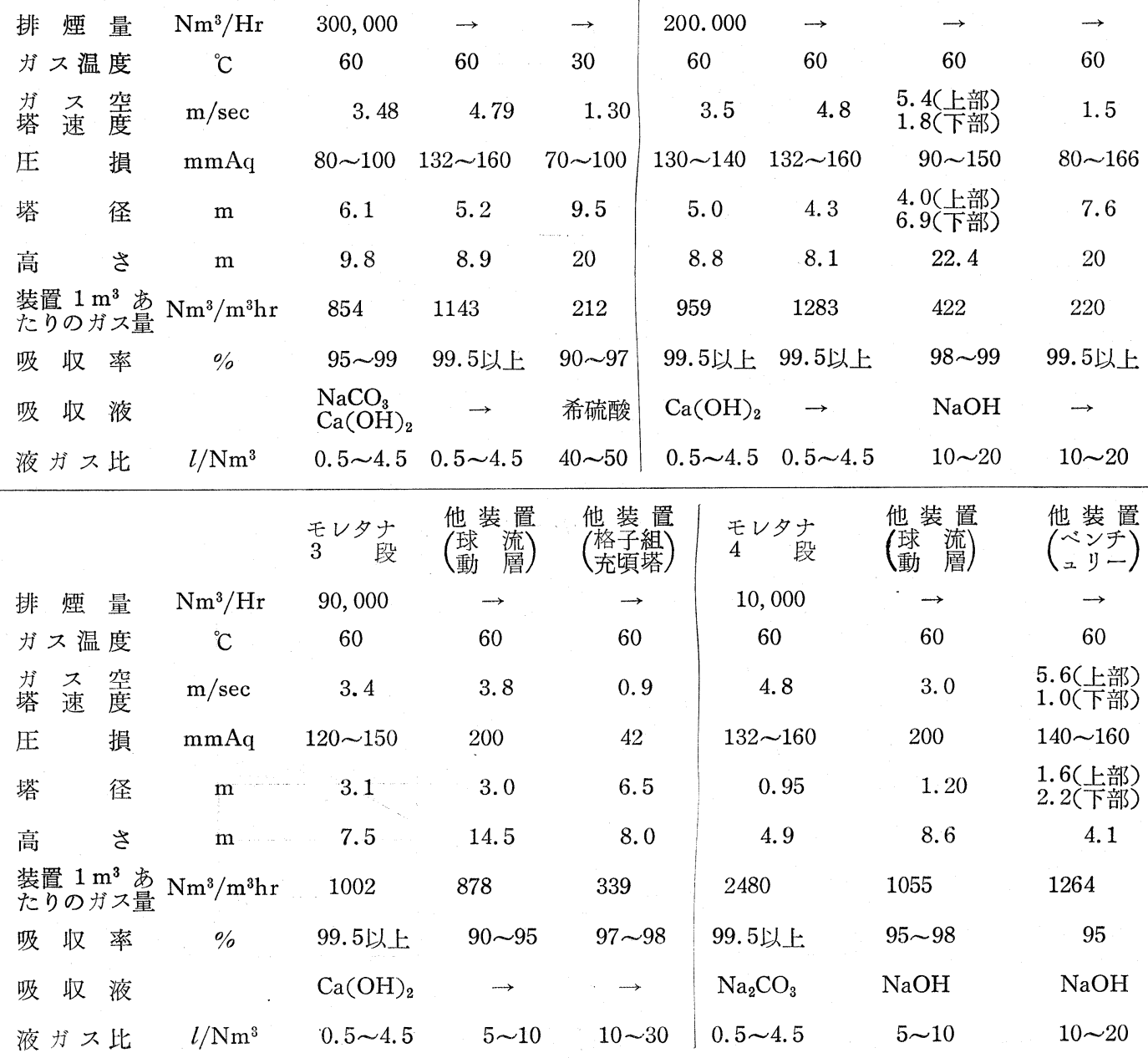


プロセスは，昭和48年より富士化水工業（株）と住友 金属工業（株）により開発された気相酸化，湿式還元 プロセスである。酸化剤仁酸化塩素 $\left(\mathrm{ClO}_{2}\right)$ また はオゾン $\left(\mathrm{O}_{3}\right)$ を使い, 還元剤には脱硫反応生成物で ある亜硫酸塩を使用する。脱硫率は $99 \%$ 以上，脱硝率 は90\%以上を示すことが実装置の運転デー夕により明 らかとなっている。

以下順を追って内容を説明する。

\section{1 主反応式}

処理対象ガスがポイラー排ガスのような燃焼系の排 ガスの場合, これに含まれる窒素酸化物はほとんどが $\mathrm{NO}$ であり，これを酸化剈により $\mathrm{NO}_{2}$ とする酸化反 応から脱硝工程が始まる。従って本プロセスを構成す る主化学反応工程は, 酸化剤発生工程と NO の酸化 工程，および吸収同時除去工程に分けられる。

以下に各々の工程に和ける化学反応式を記す。

1）酸化剤発生工程

$$
\begin{array}{cc}
\mathrm{SO}_{2} \text { 発生 } & \mathrm{Na}_{2} \mathrm{SO}_{3}+2 \mathrm{H}_{2} \mathrm{SO}_{4} \rightarrow \\
\mathrm{ClO}_{2} \text { 発生 } & 2 \mathrm{NaClO}_{3}+2 \mathrm{SO}_{2}+\mathrm{H}_{2} \mathrm{SO}_{4} \rightarrow \\
& 2 \mathrm{ClO}_{2}+2 \mathrm{NaHSO}_{4}
\end{array}
$$

酸化剂発生汇は上式の上うに塩素酸ソーダと亜硫酸 ガスを硫酸々性下で反応させる新マチソン方式を採用 している。

2) NO 酸化工程

$$
2 \mathrm{NO}+\mathrm{ClO}_{2}+\mathrm{H}_{2} \mathrm{O} \rightarrow \mathrm{NO}_{2}+\mathrm{HNO}_{3}+\mathrm{HCl}
$$

ボイラー排煙中の $\mathrm{NO}_{x}$ のように 200 400 ppm 程 度の濃度で，乙かも先の主体が NO である場合, NO を酸化して $\mathrm{NO}_{2}$ とすることが脱硝反応として最も効

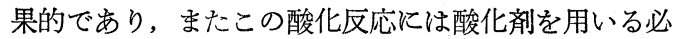
要があり，上述の反応を主としたプロセスを工業化し た。

酸化剈としては $\mathrm{ClO}_{2}$ を使用する他， $\mathrm{O}_{3}$ の使用る 可能であり，オゾンの大容量発生設備の運転費を含む コスト比較を行なって酸化㓮を選定している。

酸化剂に $\mathrm{ClO}_{2}$ を用いた場合の酸化速度は, 本プロ 七スの性能を左右する最大の要因でもあり,この効果 は図 3 の $\mathrm{NO}$ の空気酸化速度招よび図 4 の $\mathrm{NO}-\mathrm{ClO}_{2}$ 接触時間之酸化率に示す通りである。

$\mathrm{ClO}_{2}$ の $\mathrm{NO}$ に対する酸化能力は, 高濃度の $\mathrm{SO}_{2}$ ガ スの存在下に和いても，添加量は反応式通りで NOの ほぼ $1 / 2$ 当量で済み，乙かも反応接触時間は 0.3 秒以内 で $\mathrm{NO}_{x}$ をほ淁 $100 \%$ 酸化する。

$\mathrm{ClO}_{2}$ 添加量と $\mathrm{NO}$ の酸化率の関係は図 5 亿示す。

3）吸収同時除去工程
脱硫 $\mathrm{SO}_{2}+2 \mathrm{NaOH} \rightarrow \mathrm{Na}_{2} \mathrm{SO}_{3}+\mathrm{H}_{2} \mathrm{O}$

脱硝 $\mathrm{NO}_{2}+2 \mathrm{Na}_{2} \mathrm{SO}_{3} \rightarrow \frac{1}{2} \mathrm{~N}_{2}+2 \mathrm{Na}_{2} \mathrm{SO}_{4}$

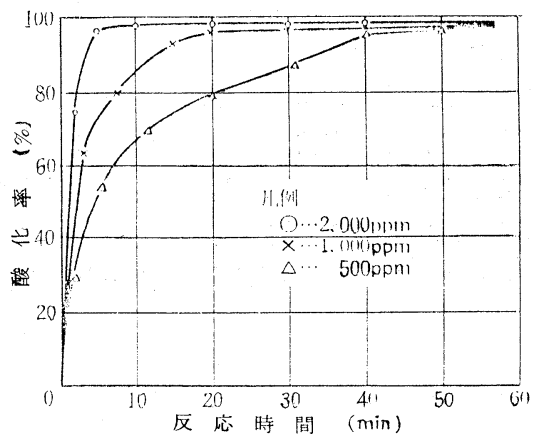

図 3 NO の空気酸化速度

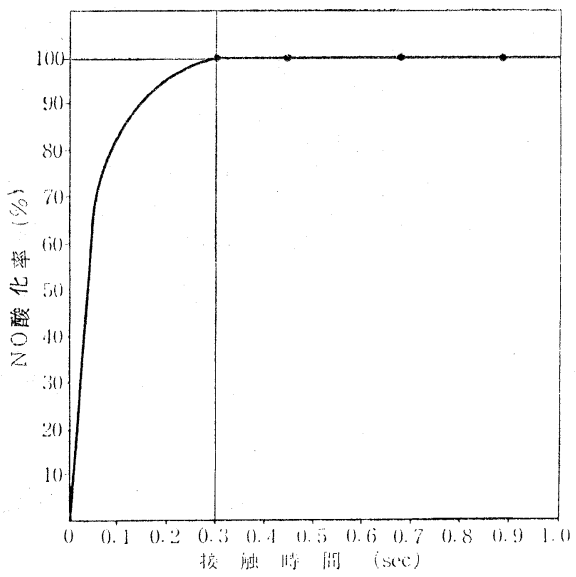

図 $4 \mathrm{NO}-\mathrm{ClO}_{2}$ 接触時間と酸化率

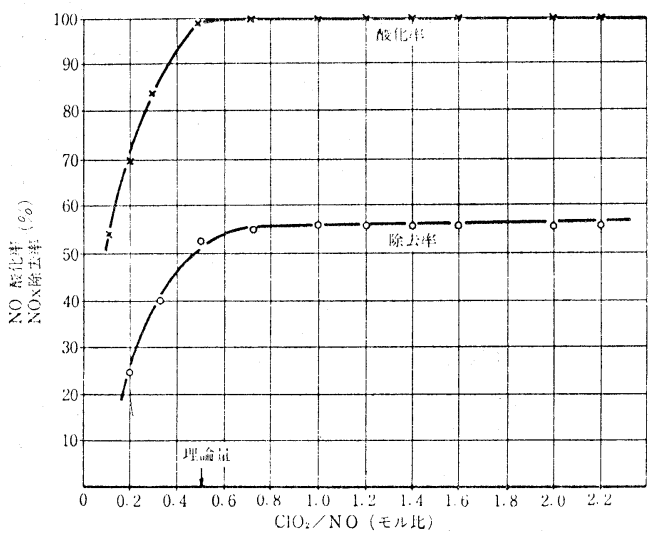

図 $5 \mathrm{ClO}_{2}$ 添加量と NO 酸化率と NO NO P $_{\text {余去率 }}$ 
酸化剤により酸化された $\mathrm{NO}_{2}$ は, 脱硫生成物であ る $\mathrm{Na}_{2} \mathrm{SO}_{3}$ により還元される。

5.2 プロセスフロー

基本的フローは図 6 に示すように，既存脱硫プロセ スに酸化剂発生設備を付加することで, 脱硝反応を行 なわせることができる。

$\mathrm{NO}$ の酸化反応は， 0.3 秒というきわめて短い滞留 時間を与えるだけで完結するため，図に示すごとく冷 却除じん塔とモレタナ吸収塔とを接続する煙道に酸化 剤を注入すれば反応は完結する。

本プロセスの特徽として以下の諸点が上げられる。
1）吸収塔がきわめて小型であり，大型ボイラなど 大容量の排ガス処理を行なう場合，例えば 100万 $\mathrm{Nm}^{3} / \mathrm{hr}$ で直径 $10 \mathrm{~m}$ であり, 所要敷地面積が非 常に少ない。

2）吸収液量と処理排ガス量の比 $L / G$ が小さく動 力費が削減される。

3）脱硫率 $99 \%$ 以上，脱硝率 $90 \%$ 以上の高除去率の 達成が容易である。

4) プロセスが簡単であり, 既設の脱硫設備の簡単 な改造で脱硝も可能となり, 建設費が安い。

5）負荷変動に対し追従性が良く，複雑な計装シス

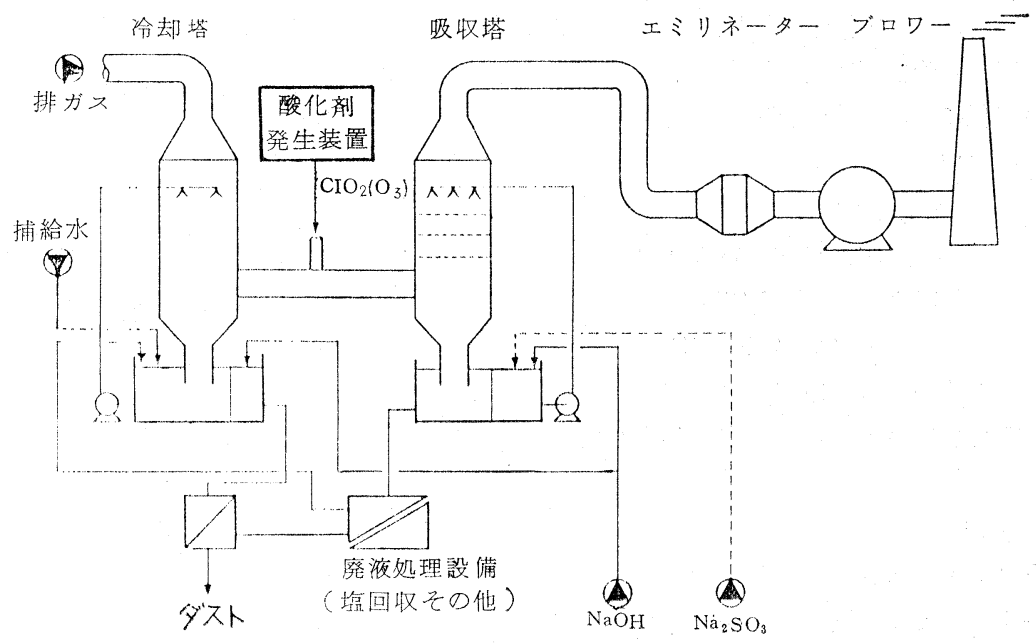

図 6 モレタナ排煙脱硫脱硝同時処理プロセスフロー

表 4 モレタナ脱硫脱硝設備および運転実績

A

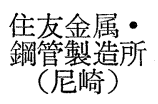

ボイラー

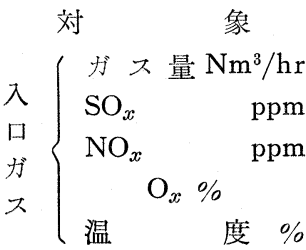

出 $\int \begin{array}{ll}\mathrm{SO}_{x} & \mathrm{ppm}\end{array}$

$\begin{cases}\mathrm{NO}_{x} & \mathrm{ppm}\end{cases}$

口温度 ${ }^{\circ} \mathrm{C}$

酸化剂

廃液処理

設置年 月

1,400

$\sim 250$

$3 \sim 4$

$150 \sim 230$

$\sim 10$

$20 \sim 30$

$50 \sim 60$

$\mathrm{ClO}_{2} \quad 0.5 \mathrm{t} / \mathrm{d}$
B

C

東伸製鋼 (姫路)

10, $000 \sim 62,000$

住友金属-
製
$($ (大䧊)

ボイラー

39,000

800

$\sim 200$

$3 \sim 4$

$100 \sim 200$

$3 \sim 6$

$15 \sim 20$

$50 \sim 60$

金属加熱炉

100,150

$300 \sim 1,150$

$100 \sim 200$

$5 \sim 7$

$350 \sim 640$

$5 \sim 10$

$5 \sim 25$

$70 \sim 75$

$\mathrm{ClO}_{2} \quad 0.2 \mathrm{t} / \mathrm{d}$

$\mathrm{ClO}_{2} \quad 0.5 \mathrm{t} / \mathrm{d}$

$\mathrm{SS}, \mathrm{PH}, \mathrm{COD}$ 調整後 放流

48年12月 49年12月

50年 1 月 
表 5 各種同時除去 プロセス

$$
\begin{aligned}
& \text { No. プロセス名主 反応式 } \\
& 1\left\{\begin{array} { c } 
{ \text { 二酸 化 塩 素〜 } } \\
{ \text { (オン゙ン) } } \\
{ \text { 苛性 (亜硫曹) 法 } }
\end{array} \left\{\begin{array}{l}
2 \mathrm{NO}+\mathrm{ClO}_{2}+\mathrm{H}_{2} \mathrm{O} \rightarrow \mathrm{NO}_{2}+\mathrm{HNO}_{3}+\mathrm{HCl} \\
\left(\mathrm{NO}+\mathrm{O}_{3} \rightarrow \mathrm{NO}_{2}+\mathrm{O}_{2}\right) \\
\mathrm{SO}_{2}+2 \mathrm{NaOH} \rightarrow \mathrm{NaSO}_{3}+\mathrm{H}_{2} \mathrm{O} \\
\mathrm{NO}_{2}+2 \mathrm{Na}_{2} \mathrm{SO}_{3} \rightarrow \frac{1}{2} \mathrm{~N}_{2}+2 \mathrm{Na}_{2} \mathrm{SO}_{4}
\end{array}\right.\right.
\end{aligned}
$$

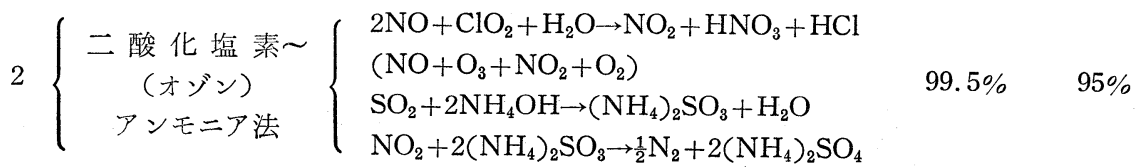

$$
\begin{aligned}
& 3\left\{\begin{array} { c } 
{ \text { 二酸化塩素〜 } } \\
{ \text { (オゾン) } } \\
{ \text { 石 灰 法 } }
\end{array} \left\{\begin{array}{l}
2 \mathrm{NO}+\mathrm{ClO}_{2}+\mathrm{H}_{2} \mathrm{O} \rightarrow \mathrm{NO}_{2}+\mathrm{HNO}_{3}+\mathrm{HCl} \\
\left(\mathrm{NO}+\mathrm{O}_{3} \rightarrow \mathrm{NO}_{2}+\mathrm{O}_{2}\right) \\
\mathrm{SO}_{2}+\mathrm{Ca}(\mathrm{OH})_{2} \rightarrow \mathrm{CaSO}_{3}+\mathrm{H}_{2} \mathrm{O} \\
\mathrm{NO}_{2}+2 \mathrm{CaSO}_{3} \rightarrow \frac{1}{2} \mathrm{~N}_{2}+2 \mathrm{CaSO}_{4}
\end{array}\right.\right.
\end{aligned}
$$

\section{テムは不要である。}

\section{3 実装置運転状況}

現在運転中の設備は表 4 の通りである。

この例は $\mathrm{NO}_{x}$ の還元に脱硫生成物である $\mathrm{Na}_{2} \mathrm{SO}_{3}$ を使用した場合であるが，例Aの場合にはボイラー重 油に $2.6 \%$ の $\mathrm{S}$ 分を含むため, 排ガス中の $\mathrm{SO}_{x}$ と $\mathrm{NO}_{x}$ の比率がうまくバランスし, 外部から $\mathrm{Na}_{2} \mathrm{SO}_{3}$ を補給する必要は全くない。また重油中の $\mathrm{S}$ 分が $2 \%$ 以上あれば脱硝に必要な $\mathrm{Na}_{2} \mathrm{SO}_{3}$ は自給できる。

\section{6. 今後の課題}

硫黄酸化物, 窒素酸化物の除去法については乾式脱 硝法と湿式脱硫法の組合せも検討されつつあるが，こ の場合の大きな問題は脱硝反応と脱硫吸収反応の温度 レベルの差による多大なエネルギーのロスである。冒 頭に述べたように脱硝を行ならことによる高額の経済 的支出は最早許容されるものではなく, 最低コストに よる脱硝プロセスの開発が必要であり, 湿式脱硫を行 なう場合には同時除去による脱硝が最も理想的である ともい党よう。 5 項の説明は $\mathrm{Na}$ 系吸収剤の使用を例 としているが， $\mathrm{Ca}$ 系吸収剤あるいはアンモニア使用 の場合においても表 5 に示す結果が得られている。い
ずれも湿式脱硫設備に酸化剤発生装置を付加するだけ でよく，低処理コストの脱硝が期待される。

今後は特に安価な $\mathrm{Ca}$ 系吸収剤を使用した同時除去 法に和けるプロセスの簡略化を計ると同時に，排水中 の窒素規制対策も検討中でめる。

\section{文献}

1) 内山 久,「漏れ棚塔によるガス吸収の原理と応 用」, 化学工場 vol. 18 , No. 4, p. 38 (1974)

2) 大島, 高崎, 「富士化水の湿式脱硝法」熱管理と 公害, vol. 27 , No. 2, p. 37 (1975)

3）曾我部捷注，「窒素酸化物の排出規制について」, 石油と石油化学 vol. 19, No. 9, p. 73 (1975)

4) 茨木英治,「湿式脱硫・脱硝装置の現状と問題 点」, 石油と石油化学, vol. 19, No. 9, p. 69 (1975)

5）上ノ山 博, 「モレタナ吸収装置による $\mathrm{NO}_{x}$, $\mathrm{SO}_{x}$ 同時除去」, 然料協会, $\mathrm{NO}_{s}$ に関するパホ ルディスカッション要旨 昭和50年 11 月

6) 安藤淳平,「脱硫・脱硝の問題点と進むべき方 向」 MOL, p. 25, 昭和 50 年 12 月 


\title{
Simultaneous Elimination of NO$x$ and $\mathrm{SO}_{x}$ Using MORETANA
} Absorber

\author{
by Hiroshi Uenoyama and Kenichi Hayakawa \\ (Japan Gasoline Co. Ltd.)
}

SYNOPSIS : - The MORETANA absorber is equipped with perforated trays of extremely simple construction for bringing liquid and gas into vigorous contact with each other.

The perforated trays in the MORETANA absorber have been designed with optimum hole openings, hole size and liquid-gas ratio. As the liquid-gas flow conditions in the MORETANA absorber are distinctly different from those of conventional absorbers, the gas space velocity is 4.5 to $5 \mathrm{~m} / \mathrm{sec}$ and the mass transfer efficiency is of a very high order. The MORETANA absorber thus enables the treatment of 2 to 7 times more gas than conventional absorbers.

Especially when used in flue gas desulfurization units, the MORETANA absorber ensures a 95 to $99 \% \mathrm{SO}_{x}$ elimination rate, even with absorbents such as $\mathrm{NaOH}$ and lime. Besides, the MORETANA absorber is not prove to scaling or clogging of solidsowing to the "self-induced washing effect" provided by the vigorous mixing of gas and liquid though such phenomena are often found in conventional absorbers using slurry fluid.

Using a MORETANA absorber having the above performance, more than $90 \%$ of $\mathrm{NO}_{x}$ is also eliminated simultaneously.

In the the MORETANA process, $\mathrm{NO}$ is oxidized by means of $\mathrm{Cl}_{2}$ or $\mathrm{O}_{3}$ (converted to $\mathrm{NO}_{2}$ ) and recovered very effectively as $\mathrm{N}_{2}$ by means of sulfite generated through desulfurization reaction.

$$
\begin{aligned}
2 \mathrm{NO}+\mathrm{ClO}_{2}+\mathrm{H}_{2} \mathrm{O} & \rightarrow \mathrm{NO}_{2}+\mathrm{HNO}_{3}+\mathrm{HCl} \\
\mathrm{NO}+\mathrm{O}_{3} & \rightarrow \mathrm{NO}_{2}+\mathrm{O}_{2} \\
\mathrm{NO}_{2}+2 \mathrm{NaSO}_{3} & \rightarrow \frac{1}{2} \mathrm{~N}_{2}+2 \mathrm{Na}_{2} \mathrm{SO}_{4} \\
\mathrm{NO}_{2}+2\left(\mathrm{NH}_{4}\right)_{2} \mathrm{SO}_{3} & \rightarrow \frac{1}{2} \mathrm{~N}_{2}+2\left(\mathrm{NH}_{4}\right)_{2} \mathrm{SO}_{4} \\
\mathrm{NO}_{2}+2 \mathrm{CaSO}_{3} & \rightarrow \frac{1}{2} \mathrm{~N}_{2}+2 \mathrm{CaSO}_{4}
\end{aligned}
$$

As actual cases of application of the MORETANA process, four (4) industrial plants are performing satisfactorily and two (2) plants are now under construction. 